J. Biosci., Vol. 13, Number 1, March 1988, pp. 39-42. (C) Printed in India.

\title{
Characterization of foot-and-mouth disease virus types $O$ and Asia 1 RNA
}

\author{
S. VASANTHA*†, S. M. LAL* and A. ANTONY§ \\ Microbiology and Cell Biology Laboratory, Indian Institute of Science, Bangalore 560012 , \\ India \\ *Indian Veterinary Research Institute, Bangalore 560 024, India \\ $\dagger$ Present address: Laboratory of Clinical Investigation, National Institute of Allergy and \\ Infectious Diseases, Bethesda, MD 20205, USA
}

MS received 27 January 1987; revised 20 December 1987

\begin{abstract}
Poly (A) RNA was isolated from foot-and-mouth disease virus-infected cells by oligo (dT)-cellulose chromatography. One-dimensional oligonucleotide mapping of virusinduced poly (A) RNA indicated major differences between virus types $\mathrm{O}$ and Asia 1. Base composition analysis of virus-induced RNA showed no significant differences between types $\mathrm{O}$ and Asia 1.
\end{abstract}

Keywords. Foot-and-mouth disease virus; poly (A) RNA; oligo (dT)-cellulose chromatography; oligonucleotide mapping; base composition analysis.

\section{Introduction}

Foot-and-mouth disease is an acute and highly contagious febrile disease affecting cloven-footed animals. Identification of the foot-and-mouth disease virus (FMDV), the causative agent of the disease, posed problems because of the occurrence of many types and subtypes of the virus. A molecular approach based on oligonucleotide mapping of FMDV RNA has been used for the identification and characterization of virus isolates obtained in a disease outbreak (King et al., 1981). One-dimensional oligonucleotide mapping was used for rapid analysis of FMDV RNA (LaTorre et al., 1982). FMDV types $\mathrm{O}$ and Asia 1 of Indian origin are being routinely used for vaccine production in India. This report presents the differences between FMDV types $\mathrm{O}$ and Asia 1 at molecular level based on one-dimensional oligonucleotide mapping of virus-induced poly (A) RNA.

\section{Materials and methods}

Actinomycin $\mathrm{D}$, oligo (dT)-cellulose type $\mathrm{T}-2$, ribonuclease $\mathrm{T}_{1}$ and ribonuclease $\mathrm{T}_{2}$ were obtained from Sigma Chemical Co., St. Louis, Missouri, USA. Carrier-free $\left[{ }^{32} \mathrm{P}\right]$-orthophosphate (activity $10 \mathrm{mCi} / \mathrm{ml}$ ) was obtained from the Bhabha Atomic Research Centre, Bombay. All other chemicals used were of analytical grade.

Isolation of $\left[{ }^{32} p\right]$-labelled poly (A) RNA from FMDV-infected BHK-21 Razi cells

BHK-21 Razi cells obtained from Razi Institute, Teheran, were grown to confluence and infected with FMDV types $\mathrm{O}$ and Asia 1 separately at multiplicity infection of

$\S$ To whom all correspondence should be addressed.

Abbreviations used: FMDV, Foot-and-mouth disease virus; CMP, cytidine monophosphate. 
10 plaque forming units/cell. The cells were first washed with phosphate-free Eagle's medium and then treated with $10 \mathrm{ml}$ of the same medium containing $5 \mu \mathrm{g} / \mathrm{ml}$ of actinomycin D. At $2 \mathrm{~h}$ post-infection $2 \mathrm{mCi}$ of carrier-free $\left[{ }^{32} \mathrm{P}\right]$-orthophosphate were added to each culture bottle. Medium was removed from cells infected with FMDV types $O$ and Asia 1 at 6 and 8 h post-infection respectively and the cells were chilled in ice. RNA was isolated from the cells by the method reported earlier (Scodeller et al., 1979; LaTorre et al., 1982). Poly (A) RNA was isolated by oligo (dT)cellulose chromatography as described by Grubman et al. (1979).

\section{One- dimensional oligonucleotide mapping of FMDV-induced poly(A) RNA}

Poly(A) RNA was digested with RNase $T_{1}$ by the method described by LaTorre et al. (1982). Digestion was carried out at an enzyme to substrate ratio of 1:20 for $60 \mathrm{~min}$ at $37^{\circ} \mathrm{C}$. The oligonucleotides were separated on $8 \%$ Polyacrylamide gel containing $8 \mathrm{M}$ urea by one-dimensional electrophoresis using the method of Sanger and Coulson (1978) with minor modifications. The ethanol precipitate obtained from RNase $\mathrm{T}_{1}$ digests was dissolved in $2 \mu \mathrm{l}$ of dye marker solution containing $80 \%(\mathrm{v} / \mathrm{v})$ formamide, $6 \mathrm{M}$ urea, $0 \cdot 2 \%$ bromophenol blue, $0 \cdot 2 \%$ xylene cyanol and $1 \mathrm{M}$ EDTA and the samples placed in the gel slots. The electrophoresis was carried out at $1200 \mathrm{~V}$ using TBE buffer, $\mathrm{pH} 8.3(10.8 \mathrm{~g}$ of Tris, $5.5 \mathrm{~g}$ boric acid and $0.93 \mathrm{~g}$ of EDTA dissolved in distilled water, $\mathrm{pH}$ adjusted to $8 \cdot 3$, made up to 1 litre). After electrophoresis the gel was subjected to autoradiography at $-70^{\circ} \mathrm{C}$.

\section{Base composition analysis}

Base composition analysis of FMDV-induced RNA was carried out by the method described by Nishimura (1972). The $\left[{ }^{32} \mathrm{P}\right]$-labelled RNA was digested with RNase $\mathrm{T}_{2}$ at $37^{\circ} \mathrm{C}$ for $20 \mathrm{~h}$. Mononucleotides from the enzyme digest were separated by paper electrophoresis at $4000 \mathrm{~V}$ for $60 \mathrm{~min}$ using pyridine buffer, $\mathrm{pH} 3.5$ (05\% pyridine, $5 \%$ acetic acid and $5 \mathrm{mM}$ EDTA). After electrophoresis the paper was exposed to Xray film overnight at $-70^{\circ} \mathrm{C}$. The spot corresponding to each nucleotide was cut out and the radioactivity was determined in a liquid scintillation counter.

\section{Results and discussion}

Oligonucleotide maps of FMDV-induced poly (A) RNA are shown in figure 1. Six major bands, A, B, C, D, E and F present in FMDV type O were not detected in the case of Asia 1 virus. No difference in poly $(\mathrm{C})$ tracks between FMDV types $\mathrm{O}$ and Asia 1 was observed. The results of base composition analysis of FMDV-induced RNA are shown in table 1 . In both types $\mathrm{O}$ and Asia 1 RNA, cytidine monophosphate (CMP) was the predominant base and no unusual bases were present.

Oligonucleotide maps have indicated differences among FMDV subtypes $\mathbf{A}_{22}$, $\mathrm{A}_{5}$ and $\mathrm{A}_{24}$ (Robson et al., 1979). Two-dimensional fingerprinting of RNase $\mathrm{T}_{1}$ digests of viral RNAs from virus isolates made during an outbreak of foot-andmouth disease in the UK, has helped to identify and characterize the isolates (King et al., 1981). The difference observed in the oligonucleotide maps of FMDV types $\mathrm{O}$ and Asia 1 RNA shows that one-dimensional oligonucleotide mapping can be used 


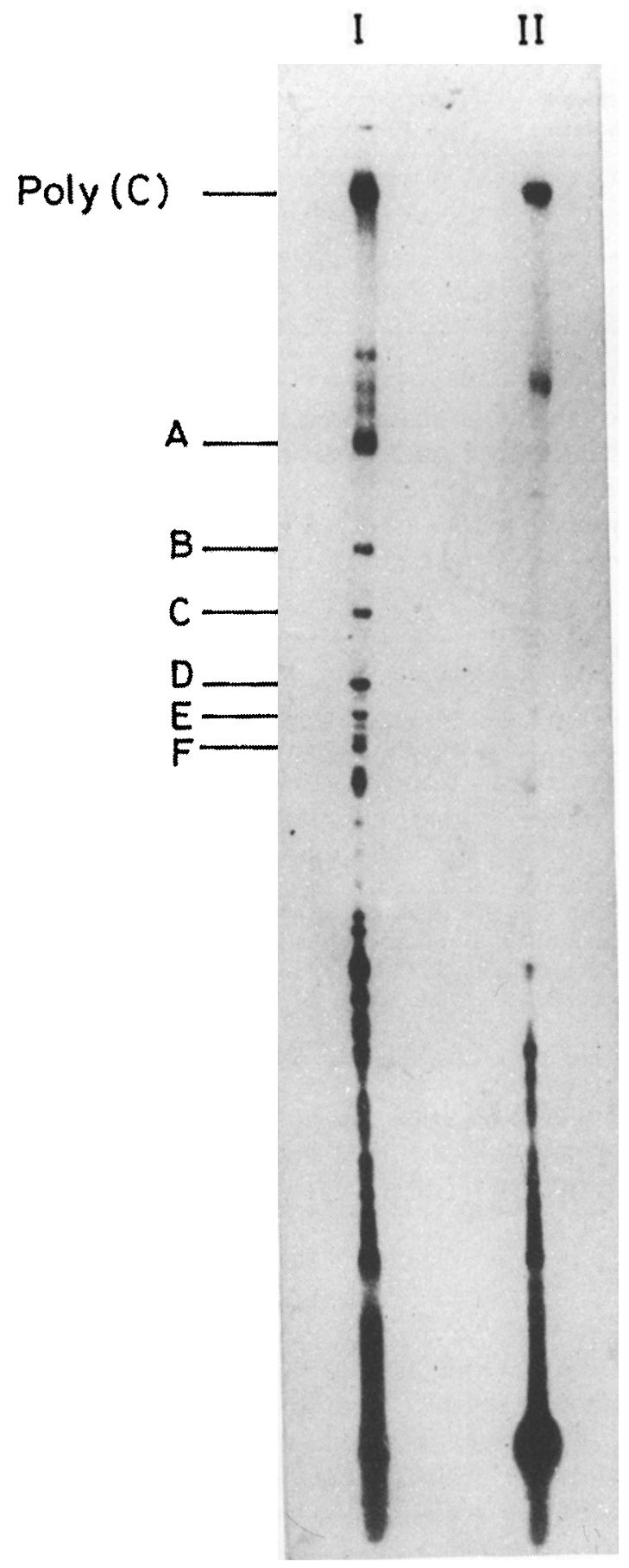

Figure 1. One-dimensional oligonucleotide mapping of FMDV types $\mathrm{O}$ and Asia 1 induced Poly (A) RNA. To each slot $50,000 \mathrm{cpm}$ of oligonucleotides was applied Lane I. FMDV type O; Lane II, FMDV Asia 1. 
Table 1. Base composition analysis of FMDV types $\mathrm{O}$ and Asia 1 RNA.

\begin{tabular}{lcc}
\hline & \multicolumn{2}{c}{ Mole (\%) } \\
\cline { 2 - 3 } Ribonucleoside \\
\cline { 2 - 3 } monophosphate & FMDV type O & FMDV type Asia 1 \\
\hline CMP & $29 \cdot 5$ & $31 \cdot 5$ \\
AMP & $21 \cdot 8$ & $25 \cdot 1$ \\
GMP & $26 \cdot 6$ & $21 \cdot 4$ \\
UMP & $22 \cdot 1$ & $22 \cdot 0$ \\
G+C & $56 \cdot 1$ & $52 \cdot 9$ \\
\hline
\end{tabular}

as a rapid method to distinguish between FMDV types and subtypes. This is often important in epidemiological studies particularly where the disease is endemic and antigenic variation is more likely. The present finding that CMP is the predominant base in FMDV types $\mathrm{O}$ and Asia 1 RNA is in agreement with that reported in the case of FMDV types A, O and C (Bachrach, 1977).

\section{Acknowledgement}

The authors thank Prof. G. Padmanaban, Biochemistry Department for providing facilities in his laboratory and for helpful discussion.

\section{References}

Bachrach, H. L. (1977) in Beltsville Symposia in agricultural research 1. Virology in agriculture (ed. J. A. Romberger) (Montoclair: Allanheld, Osmum and Co.) p. 3.

Grubman, M. J., Baxt, B. and Bachrach, H. L. (1979) Virology, 97, 22.

King, A. M. Q., Underwood, B. O., McCahon, D., Newman, J. W. I. and Brown, F. (1981) Nature (London), 293, 479.

LaTorre, J. L., Underwood, B. O., Lebendiker, M., Gorman, B. M. and Brown, F. (1982) Infect. Immun., 36, 142.

Nishimura, S. (1972) Prog. Nucleic Acid Res. Mol. Biol, 12, 49.

Robson, K. J. H., Crowther, J. R., King, A. M. Q. and Brown, F. (1979) J. Gen. Virol., 45, 579.

Sanger, F. and Coulson, A. R. (1978) FEBS Lett., 87, 107.

Scodeller, E., Denoya, C. D., Vasquez, C. and LaTorre, J. L. (1979) Arch. Virol, 62, 253. 